\title{
De tragiek van audit quality indicatoren (AQI's)
}

\author{
Herman van Brenk, Edgar Karssing, Ivo De Loo, Barbara Majoor
}

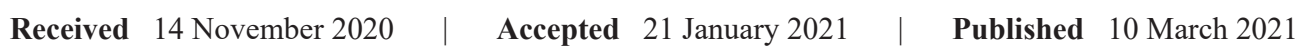

\section{Samenvatting}

In dit artikel geven wij een kritische reflectie op het rapporteren van audit quality indicatoren (hierna: AQI's) door accountants om het vertrouwen in de accountancysector terug te winnen. Wij doen dit aan de hand van een klassieke tragedie waarin de held 'het goede' beoogt en 'het kwade' bereikt. Op basis van verschillende kenmerken, die inherent zijn aan het accountantsberoep, beargumenteren wij waarom het rapporteren van AQI's niet datgene brengen kan wat er van wordt verwacht. Daarna geven wij enkele handreikingen die kunnen helpen om met deze tragiek om te gaan zodat er ruimte ontstaat voor de verdere ontwikkeling van controlekwaliteit.

\section{Relevantie voor de praktijk}

Dit artikel is relevant voor opstellers, controleurs en gebruikers van jaarrekeningen om een beter begrip te krijgen bij de inherente beperkingen van AQI's. Onze aanbevelingen kunnen bijdragen aan een gezond evenwicht tussen accountants en wat ook wel 'de maatschappij' wordt genoemd met betrekking tot het duiden en leren van controlekwaliteit. Beleidsmakers kunnen onze inzichten gebruiken in het verder ontwikkelen en vormgeven van AQI's.

\section{Trefwoorden}

controlekwaliteit; indicatoren; verhalen; tragiek; toekomst accountancy

\section{Inleiding}

Het accountantsberoep ligt de laatste tijd onder het vergrootglas van onder meer de politiek. Belangrijke aanleidingen hiervoor zijn diverse fraudeschandalen (zoals bij Imtech en Steinhoff) en kritische rapportages van de Autoriteit Financiële Markten (AFM) over de kwaliteit van door accountants uitgevoerde wettelijke controles. Inmiddels zijn er meerdere rapporten gepubliceerd door verschillende commissies, waaronder de Monitoring Commissie Accountancy (MCA 2020) en Commissie Toekomst Accountancysector (CTA 2020). In deze rapporten zijn diverse maatregelen voorgesteld die moeten leiden tot een duurzame verhoging van de kwaliteit in de accountancysector. De minister van Financiën heeft in een kabinetsreactie gereageerd op deze rapporteren waarna een debat heeft plaatsgevonden met de Tweede Kamer. Ook heeft de minister van Financiën twee kwartiermakers benoemd die de voortgang en samenhang van de maatregelen uit de kabinetsreactie moeten bevorderen en monitoren. De kwartiermakers beschrijven in hun plan van aanpak dat het hun rol is om ervoor te zorgen dat er breed gedragen AQI's worden vastgesteld (De Vries et al. 2020). Wij richten ons in dit artikel op de tragiek die kan ontstaan als gevolg van het plan van de kwartiermakers om AQI's op te stellen en de accountancysector hierover stelselmatig te laten rapporteren.

Tragiek is een begrip uit de Griekse oudheid en betekent dat men door 'het goede' te willen doen 'het kwade' over zichzelf of anderen afroept. ${ }^{1}$ Ter illustratie geven wij een samenvatting van de klassieke tragedie van Oedipus (zie ook Karssing 2018):

Koning Laios hoort van het Orakel dat zijn pasgeboren zoon, Oedipus, hem zal vermoorden. Om dit te voorkomen wil hij zijn zoon laten vermoorden. Deze opdracht wordt echter niet uitgevoerd en Oedipus komt via via 
terecht bij een kinderloos koningspaar waar hij opgroeit als hun zoon en erfgenaam. Als Oedipus op zijn beurt van het Orakel verneemt dat hij zijn vader zal vermoorden en met zijn moeder zal trouwen, vlucht hij bij zijn ouders weg, bij de mensen waarvan hij denkt dat het zijn ouders zijn. Op zijn zwerftocht vermoordt hij zijn biologische vader - als iemand die weigert voor hem aan de kant te gaan - en trouwt hij met zijn biologische moeder - precies zoals het Orakel had voorspeld. Als hij eenmaal begrijpt wat er aan de hand is, steekt hij zijn eigen ogen uit.

De tragedie is een klassieke kunstvorm die als belangrijke les meegeeft dat het streven naar 'het goede' onbedoeld kan resulteren in het tegendeel. De tragische ironie is dat Oedipus precies het tegendeel bereikte van wat hij beoogde. Ziende blind liep hij zijn eigen ondergang tegemoet. Dit tragische kan een innerlijk conflict oproepen: zijn mensen wel of niet schuldig aan de bezoedeling van 'het goede'? Oedipus legde de schuld bij zichzelf en stak zijn eigen ogen uit. De tragiek ontstond echter door omstandigheden die hij niet zelf had gekozen. Hoe pijnlijk is het dan als men willens en wetens tragiek opzoekt, als mensen zelf het tragische in de wereld vergroten, als zij mede schuldig worden aan hun eigen lot? De les van de klassieke tragedies is om tijdig in te zien dat goed bedoelde handelingen te allen tijde kwade gevolgen kunnen en misschien ook zullen hebben. In dit artikel passen wij deze les toe op het rapporteren van AQI's.

De link tussen tragiek en AQI's sluit aan bij de constatering van de CTA dat er nauwelijks informatie beschikbaar is over "relevante factoren voor accountants om 'het goede te doen"' (CTA 2020, p. 6). Op grond hiervan doet de CTA de aanbeveling om de kwaliteit van wettelijke controles beter inzichtelijk te maken met behulp van de voornoemde AQI's die uniform en representatief zouden moeten zijn om een vergelijking tussen accountantsorganisaties te vergemakkelijken. Het is een interessante gedachte van de CTA om het rapporteren van AQI's te koppelen aan het filosofische idee van 'het goede doen'. Maar wat is precies 'het goede'? Wanneer doet iemand 'het goede'? En wanneer is 'het goede' goed (genoeg)? Hoewel 'het goede doen' niet expliciet is gedefinieerd door de CTA lijkt het te zijn gericht op de kwaliteit van wettelijke controles. Deze focus op kwaliteit zorgt voor een dilemma, aangezien uit wetenschappelijke literatuur blijkt dat er geen eenduidige maatstaf bestaat om controlekwaliteit vast te stellen en te meten (Detzen and Gold 2021; Knechel et al. 2013; Van Buuren 2015), waardoor het idee van representativiteit en uniformiteit in essentie wordt ondermijnd. Dit dilemma van weten of denken dat er een eenduidig begrip van kwaliteit kan bestaan en tegelijkertijd niet weten wat dit precies is, vraagt volgens ons om een kritische reflectie.

Hoewel het meten en rapporteren van AQI's een stap vooruit lijkt te zijn in discussies over kwaliteit in de accountancysector, brengt het veel complexiteit met zich mee aangezien er, naast onduidelijkheid over wat controlekwaliteit precies is, nog weinig consensus bestaat welke indicatoren controlekwaliteit verklaren (Majoor 2016). Wij gaan nog een stap verder door te stellen dat het accountantsberoep zich niet zo goed leent voor het objecti- veren en kwantificeren van kwaliteit. Bij het rapporteren van AQI's wordt het object (de indicator) namelijk losgekoppeld van het subject of de geest (de accountant die bepaalde controlewerkzaamheden verricht), alsof controlekwaliteit tot enkele getallen kan worden gereduceerd. Deze scheiding miskent het subjectieve en gevoelsmatige element dat ook onderdeel is van controlekwaliteit, en hier een aanzienlijk deel van kan uitmaken. Daarnaast gaat het rapporteren van AQI's op organisatieniveau voorbij aan onderzoek dat heeft aangetoond dat zowel investeerders als accountants de individuele kenmerken van accountants zien als de belangrijkste determinanten van controlekwaliteit (Christensen et al. 2016). Zoals Van Brenk et al. (2017, p. 2) hebben aangegeven, is het aggregeren van individuele kenmerken "als het drinken van een smoothie: het smaakt naar fruit maar je weet niet precies welke vruchten zijn gebruikt." Het rapporteren van kwantitatieve AQI's op organisatieniveau en het loskoppelen van object en subject zijn volgens ons een vergaande versimpeling van de werkelijkheid en doen wellicht eerder afbreuk aan het inzicht in controlekwaliteit dan dat het een stap in de goede richting is. Tragiek komt dan mogelijk heel dichtbij.

Moet het accountantsberoep dan maar lijdzaam toezien op het besluitvormingsproces van de minister die relatief ver afstaat van de dagelijkse accountantspraktijk? Hiervoor sluiten wij ons aan bij Aristoteles die in zijn Ethica Nicomachea uitgaat van het 'deugdzame' midden van twee uitersten. In de context van AQI's betekent dit het midden kiezen tussen hoogmoed enerzijds (actief rapporteren) en fatalisme anderzijds (niets doen). De sleutel hiervoor ligt bij de accountants, bijvoorbeeld in de vorm van een dialoog met stakeholders in de keten (zie de transparantieverslagen van accountantsorganisaties). Hierbij is het belangrijk dat accountants zich kwetsbaar opstellen en laten zien wat het verhaal is achter hun uitgevoerde werkzaamheden. In dit artikel geven wij een handreiking om hier verder mee aan de slag te gaan. In paragraaf 2 beschrijven we enkele bronnen van tragiek en in paragraaf 3 geven wij suggesties hoe accountants met deze bronnen kunnen omgaan. Paragraaf 4 bevat de conclusies van dit artikel.

\section{Bronnen van tragiek}

In deze paragraaf gaan wij dieper in op verschillende kenmerken van het accountantsberoep die de tragiek ten aanzien van AQI's kunnen vergroten. Op basis van deze bronnen van tragiek beargumenteren wij waarom AQI's minder geschikt zijn om een indruk te krijgen van controlekwaliteit dan in het publieke debat wordt betoogd.

\subsection{Geen eenduidig normenkader}

De controle van jaarrekeningen kenmerkt zich door het toetsen aan normen. Nederlandse normen voor het opstellen van jaarrekeningen zijn opgenomen in de Richtlijnen voor jaarverslaggeving (RJ). Voor het controleren van jaarrekeningen gelden in Nederland de Nadere voorschriften controle- en overige standaarden (NV COS; NBA 2020). 
Deze normen zijn opgebouwd vanuit doelstellingen die op principes zijn gebaseerd. Tijdens de jaarrekeningcontrole passen accountants professionele oordeelsvorming toe en handhaven een professioneel-kritische instelling.

De oproep van de CTA aan de accountancysector om uniform en eenduidig te rapporteren over kwaliteit sluit aan bij het idee dat controlekwaliteit een grijpbaar fenomeen zou zijn dat op eenduidige wijze kan worden gelinkt aan de werkzaamheden van accountants, de kwaliteit van de jaarrekening en het reilen en zeilen in een organisatie. Briloff (1972) constateerde al dat dit wereldbeeld gangbaar is binnen het vakgebied van accounting (zie tevens Humphrey et al. 2018; Macintosh 2009), dus in dat opzicht is het helemaal niet verwonderlijk dat de CTA deze oproep aan de sector heeft gedaan. Inherent aan het normenkader van accountants is echter ook dat er geen eenduidige normen bestaan voor het opstellen en controleren van jaarrekeningen. Eenduidige en uniforme AQI's, als een afgeleide van deze werkzaamheden van accountants, zijn daarmee volgens ons een contradictio in terminis.

De veronderstelling achter het idee dat er eenduidige AQI's zouden bestaan is gebaseerd op het hiervoor genoemde wereldbeeld dat gangbaar is binnen accounting en bekend staat als 'Cartesian dualism' (Stewart and Mickunas 1974). Dit is een wereldbeeld dat rechtstreeks uit de natuurwetenschappen afkomstig is, waarbij wordt uitgegaan van de gedachte dat er een concrete en tastbare wereld met materiële objecten bestaat (buiten mensen om en om hen heen), die tot op zeer grote hoogte geduid en gevat kan worden mits onderzoekers (zoals accountants) hun best doen en adequate metingen verrichten van specifieke objecten in die tastbare wereld en hun onderlinge relatie(s). Denk hierbij aan onderzoek naar de leeftijd van een boom of het functioneren van een auto. Op het moment dat er geen sprake is van een duidelijk aanwijsbaar materieel object, maar dat hierover ogenschijnlijk wel op eenduidige wijze wordt gesproken, hebben we te maken met een sociaal geconstrueerd fenomeen. Denk hierbij aan gevoelens van mensen. Er zijn signalen op te vangen dat iemand bepaalde gevoelens ervaart (bijvoorbeeld huilen of schreeuwen), maar wat er precies aan de hand is - of er wellicht sprake is van verdriet, woede, pijn, of een combinatie daarvan - zal tot op zekere hoogte een inschatting blijven. We zijn daarbij doorgaans aangewezen op wat iemand zelf van zijn of haar gevoelens denkt, voor zover deze al in woorden kunnen worden uitgedrukt. Controlekwaliteit is ook zo'n sociaal geconstrueerd fenomeen waarbij geen sprake is van een direct waarneembaar materieel object waar het aan gekoppeld is.

\subsection{Reductionisme}

Het normenkader van accountants richt zich vooral op het inschatten van risico's van materieel belang voor de jaarrekening. Op het niveau van beweringen over transactiestromen, jaarrekeningposten en toelichtingen gaat het om het voorkomen, de volledigheid, de nauwkeurigheid, de afgrenzing, de classificatie en de presentatie van transacties die plaatsvinden binnen organisaties (Standaard
315.A129; NBA 2020), waarvan het resultaat wordt weergegeven in een jaarrekening. Bij het opstellen van de jaarrekening vinden, in het kader van het maken van dergelijke samenvattingen, reductieslagen plaats en worden aannames gedaan. Het dagelijkse reilen en zeilen binnen een organisatie laat zich immers niet volledig noch eenduidig in een reeks van getallen tot uitdrukking brengen (Briloff 1972; Macintosh 2009; Morgan 1988). De sfeer op de werkvloer, hoe mensen met elkaar omgaan, hoe een organisatie in het nieuws komt of hoe zij zich presenteert op sociale media kunnen van groot belang zijn voor een organisatie, maar zijn niet noodzakelijkerwijs zichtbaar in de cijfers. Daarnaast kunnen cijfers zijn gekleurd door interne machtsverhoudingen binnen een organisatie, voorkeuren vanuit het verleden of ontwikkelingen bij concurrenten (Gambling 1977, 1987; Demirag and Khadaroo 2011; Ezzamel and Burns 2005). Een jaarrekening is dus hooguit een representatie van de werkelijkheid en kan deze werkelijkheid nooit volledig of op eenduidige wijze (be)vatten. Hierdoor is sprake van reductionisme in het opstellen van de jaarrekening.

Ook in het controleren van de jaarrekening is sprake van reductionisme. Voorbeelden hiervan zijn het gebruik van steekproeven en checklists in de accountantscontrole. Bij steekproeven heeft de inschatting van het steekproefrisico door de accountant invloed op de steekproefomvang, waardoor zaken niet meegenomen kunnen worden in de steekproef. Daarnaast is het mogelijk dat de populatie niet volledig was. Bij checklists bestaat het risico dat niet is voorzien in specifieke zaken die relevant zijn voor de controle van de jaarrekening bij een betreffende cliënt. In beide gevallen is sprake van een vereenvoudiging van de werkelijkheid.

Bij het opstellen en rapporteren van AQI's is er vervolgens opnieuw sprake van reductionisme, aangezien er gemiddeldes worden berekend op basis van een groot aantal opdrachten die zijn uitgevoerd door meerdere mensen. Daarnaast worden veel aspecten van de uitgevoerde werkzaamheden door controleteams buiten beschouwing gelaten wanneer zij hun rapportages opmaken. AQI's zijn hier een afgeleide van. Welke informatiewaarde hebben deze sterk vereenvoudigde en noodzakelijk beperkte indicatoren dan precies, behalve het geven van een indruk?

Door al de bovengenoemde reductieslagen zullen we mogelijk nooit (helemaal) weten of accountants hun werkzaamheden goed hebben uitgevoerd en in hoeverre daadwerkelijk sprake is van een 'goede' controle. Het opstellen en controleren van jaarrekeningen blijft immers in belangrijke mate mensenwerk. Daarnaast kan accountantscontrole worden gekenmerkt als een vertrouwensgoed waar professionele oordeelsvorming een belangrijke rol speelt en kwaliteit moeilijk is vast te stellen (Causholli and Knechel 2012). Desondanks heeft de Limpergiaanse notie van accountants als vertrouwenspersoon van het maatschappelijk verkeer haast mythische proporties gekregen die moeilijk waargemaakt kunnen worden (zie tevens Sterling 1979). Dat blijkt telkens opnieuw als er een fraude- of boekhoudschandaal in het nieuws komt zonder dat accountants de maatschappij hiervoor hebben gewaarschuwd. De tragiek hierin is onder meer dat accountants 
niet altijd in staat zijn om alles te zien en gebonden zijn aan hun eigen regelgeving die een geheimhoudingsplicht kent (Wet toezicht accountantsorganisaties, artikel 63a; Verordening gedrags- en beroepsregels accountants, paragraaf 2.6; NBA 2020), terwijl ze ondanks hun goede bedoelingen wel worden aangesproken op deze schandalen.

\subsection{Kloof tussen perceptie en werkelijkheid}

Hoewel accountants zich doorgaans bewust zijn van het feit dat cijfers in de jaarrekening geen accurate, laat staan volledige, weergave zijn van de complexe werkelijkheid in organisaties, worden deze cijfers in de perceptie van wat 'de maatschappij' wordt genoemd veelal wel als zodanig gepercipieerd. Morgan (1988) formuleert dit als volgt:

"Accountants have long recognized the limitations of numerical modes of representation, but have been hamstrung in their attempts to overcome them ... [this has happened] because the numerical view [of accounting] has been equated with an objective view. The idea that accountants represent reality "as is" through the means of numbers that are objective and value free, has clouded the much more important insight that accountants are always engaged in interpreting a complex reality, partially, and in a way that is heavily weighted in favour of what the accountant is able to measure and chooses to measure, through the particular schemes of accounting to be adopted" (Morgan 1988, p. 480, cursiveringen in origineel).

Op basis van deze conclusie van Morgan komt een kloof naar voren tussen de visie van accountants en de maatschappij rond de mate van subjectiviteit van cijfers. Deze frictie tussen objectiviteit en subjectiviteit, die inherent is aan het werk dat accountants doen, sluit aan bij de verwachtingskloof zoals onderkend door Porter (1993), waarbij prestaties van accountants niet altijd aansluiten bij de normen die aan hen worden gesteld, en deze normen weer niet altijd aansluiten bij de heersende verwachtingen van de maatschappij of het handelen van accountants. De werkelijkheid zoals accountants die ervaren op basis van hun controle kan dus afwijken van de interpretatie van de werkelijkheid door de maatschappij. Wordt er voldoende actie ondernomen om deze kloof te verkleinen? Macintosh (2009) is kritisch en pleit voor een herbezinning op de rol van accountants omdat zij in feite hun maatschappelijke plicht ontlopen door deze kloof tussen objectiviteit en subjectiviteit te laten voortbestaan of te marginaliseren. Op basis van een uitgebreide literatuurstudie concludeert Quick (2020) dat de verwachtingskloof al meer dan 50 jaar bestaat en dat het tot op heden niet is gelukt deze te dichten. Of dit nu te maken heeft met onredelijke verwachtingen van de gebruikers of dat accountants het ondanks vele pogingen (zoals de uitgebreide controleverklaring) niet lukt om deze kloof te dichten, is een tot op heden niet beantwoorde vraag (Majoor 2020).

Het rapporteren van AQI's lijkt een deugdzame stap om de kloof tussen wat accountants doen en wat de maatschappij daarvan ziet te verkleinen (FRC 2020). Daarmee moet niet worden gedacht dat objectief kan worden vastgesteld dat accountants hun werk goed hebben gedaan. AQI's bieden daarom waarschijnlijk niet het vertrouwen dat er in het debat rond de toekomst van het accountantsberoep aan pleegt te worden gekoppeld. Subjectieve normen en professionele oordeelsvorming van accountants spelen hierin een belangrijke rol.

\subsection{Subjectieve normen voor AQI's}

Bovenop het reductionisme in de totstandkoming van AQI's, zijn er kritische kanttekeningen te plaatsen bij het normenkader om deze AQI's te beoordelen. AQI's zijn een cijfermatige afgeleide van het sociaal geconstrueerde fenomeen controlekwaliteit. Dit fenomeen is niet eenduidig te definiëren of te meten, zoals we in het voorafgaande hebben aangegeven. Hierdoor is het onmogelijk om eenduidige normen te ontwikkelen om de AQI's van diverse accountantsorganisaties met elkaar te vergelijken. Toch zal deze vergelijking mogelijk snel worden gemaakt zodra AQI's zijn geïntroduceerd (FRC 2020). Een voorbeeld is het aantal bevindingen uit interne kwaliteitsreviews. Waarom is een lagere score op deze AQI een indicatie van een hogere controlekwaliteit? Dit lagere aantal bevindingen kan namelijk worden beïnvloed door een veelheid aan factoren, zoals de kwaliteit van de interne reviewers om fouten te signaleren, de overtuigingskracht van de betrokken audit partners om bevindingen te weerleggen, de kwaliteit van het controleteam om goede controles uit te voeren en/of de focus van accountantsorganisaties op cliënten met een laag risicoprofiel waar minder snel fouten worden gemaakt in de accountantscontrole. Het gevolg is dat accountants worden afgerekend op grond van sterk subjectieve cijfers zonder dat zij inzicht hebben kunnen geven in de morele overwegingen die een rol hebben gespeeld in de uitvoering van hun werkzaamheden. Kortom, de cijfers gaan gepaard met een schijn van eenduidigheid maar vertellen niet het hele verhaal.

Accountants hebben een belangrijke rol in de maatschappij met betrekking tot het controleren van jaarrekeningen. Hiermee leveren zij een bijdrage aan het inzicht in de complexe werkelijkheid van organisaties. Het kwaliteitsniveau van deze bijdrage kan variëren per accountant, controleteam, gecontroleerde organisatie en accountantsorganisatie. Inherent aan de functie van accountantscontrole is dat controlekwaliteit niet op een objectieve wijze kan worden gemeten, dat er sprake is van reductionisme in het samenstellen en controleren van jaarrekeningen en dat het normenkader voor een groot gedeelte is gebaseerd op principes die op meerdere manieren geïnterpreteerd kunnen worden (Briloff 1972; Morgan 1988). Het rapporteren van AQI's zal hier volgens ons niets aan veranderen en zal de verwachtingskloof wellicht eerder vergroten dan verkleinen als gevolg van de onmogelijkheid om eenduidige normen voor AQI's te bepalen die boven alle twijfel verheven zijn. De tragiek van AQI's is daarmee dat deze cijfermatige poging om meer inzicht te geven in de complexiteit van accountantscontrole wel eens zou kunnen leiden tot een grotere spraakverwarring over wat accountants precies hebben gezien of geconstateerd en hoe zij dat hebben gewogen. 


\subsection{Motivatie en professionele oordeelsvorming zijn niet universeel}

In hun opgestelde raamwerk van AQI's, identificeren Knechel et al. (2013) vijf fundamentele kenmerken die van invloed zijn op controlekwaliteit: (1) economische motieven, (2) een onzekere en niet observeerbare uitkomst, (3) het unieke karakter van iedere controleopdracht, (4) het doorlopen van een systematisch proces en (5) individuele oordeelsvorming van professionals. Deze kenmerken impliceren dat een accountantscontrole een activiteit is waarin individuele accountants in iedere controleopdracht weloverwogen keuzes maken die aanwijsbaar zijn gevoed vanuit hun training, kennis en ervaring (Standaard 200). Daarnaast wordt verondersteld dat accountants een professioneel-kritische instelling hebben (Standaard 200). Deze kenmerken maken dat iedere controleopdracht uniek is en dat controlekwaliteit in hoge mate wordt bepaald door het toepassen van individuele vaardigheden. Geaggregeerde indicatoren zijn daarom niet in staat om een integraal en representatief beeld van de professionele activiteiten van accountants te geven.

Veel AQI's zijn gericht op het vierde kenmerk zoals geïdentificeerd door Knechel et al. (2013), namelijk de kwaliteit van het controleproces. Kwaliteit wordt dan bijvoorbeeld tot uitdrukking gebracht in het aantal trainingsuren, het aantal kwaliteitsreviews, de 'span of control' van audit partners, het aantal experts of specialisten dat is betrokken bij complexe controleopdrachten, het aantal jaar ervaring en de investeringen in nieuwe controlemethodologie en -tools (FRC 2020; Majoor 2016). Deze indicatoren zijn eenvoudig te meten maar geven geen inzicht in de overige kenmerken van controlekwaliteit die veelal minder tastbaar en zichtbaar zijn. Daarnaast zijn deze AQI's vooral gericht op de inputzijde van controlekwaliteit en veel minder op het proces waarin professionals afwegingen maken op basis van unieke omstandigheden. In de kwaliteitsbeleving van het maatschappelijk verkeer is het resultaat van deze unieke afwegingen op basis van een ethische en kritische houding van accountants belangrijker dan de meer generieke en rationele vaktechnische inspanningen die zijn geleverd.

\section{Omgaan met tragiek}

In paragraaf 2 hebben wij verschillende bronnen van tragiek uitgewerkt in het rapporteren van AQI's door de accountancysector. In de klassieke betekenis van een tragedie is tragisch niet slechts een synoniem voor iets wat dramatisch, pijnlijk, treurig of zielig is. Tragiek ontstaat doordat een 'held' het goede nastreeft maar - door tragische omstandigheden - precies het tegendeel van wat hij beoogde realiseert (dus iemand zoals Oedipus). De tragische held veroorzaakt een mislukking ondanks en dankzij het verlangen om 'het goede' te doen. In de context van ons artikel zijn (met name) accountants de tragische held die 'het goede' willen doen. Zij willen het vertrouwen van de maatschappij terugwinnen door middel van het rapporteren van AQI's. Hoe kunnen accountants in deze situatie omgaan met tragiek? In deze paragraaf geven wij enkele suggesties hieromtrent.

\subsection{Schipperen tussen hoogmoed en fatalisme}

In het zoeken naar een manier om met tragiek om te gaan nemen wij een belangrijk advies van Aristoteles ter harte (zie ook Karssing 2018). Volgens Aristoteles is het goede, het deugdzame, het midden tussen twee uitersten. Om het juiste midden te vinden moet rekening worden gehouden met alle omstandigheden die in een bepaalde situatie een rol spelen. Hierbij is het in de eerste plaats belangrijk om inzicht te krijgen in de twee uitersten. Daarna kan de beweging naar het midden worden gemaakt. Deze zoektocht naar het midden kan ook worden toegepast bij tragiek.

De twee uitersten bij het omgaan met tragiek zijn hoogmoed en fatalisme. Hoogmoed ontkent de tragiek of denkt dat de tragiek kan worden afgewend. Bij hoogmoed gaat het om overdreven trots, overmoed en grootheidswaanzin. Bijvoorbeeld: we leven in een maakbare wereld waarin (bijna) alles kan worden gemeten, waarin we (bijna) alles weten en waarin we verder komen door nader onderzoek te doen en/of de juiste risicomodellen te implementeren. Dus, wie op de juiste knoppen drukt, krijgt het beoogde resultaat. En als er dan toch gebeurtenissen zijn die we niet hadden voorzien - als iets wat ons van buitenaf overkomt dan noemen we dat geen tragiek, maar een gebrek aan kennis of een verkeerd ontwerp. Kortom, het leven is maakbaar, we kunnen actief ons lot beheersen. En als iemand faalt? Dan heeft diegene dat aan zichzelf te wijten. De held schiet tekort, faalt en is schuldig. Terecht dat hij vervolgens zijn ogen uitsteekt. Het is daarom een vorm van hoogmoed om de tragiek in het rapporteren van AQI's te ontkennen of te denken dat controlekwaliteit maakbaar en meetbaar is.

Fatalisme is het andere uiterste van het omgaan met tragiek. Het staat voor gelatenheid en slachtofferschap en erkent tegelijkertijd dat mislukking bij het leven hoort. Hoewel fatalisme de tragische dimensie van het menselijk handelen erkent en daarmee recht doet aan de werkelijkheid, zakt het weg in passiviteit en klagen. Wat daarna overblijft is het lijdzaam meegaan in tragiek: we zijn allemaal slachtoffers, onschuldige slachtoffers, maar wel gekwetst. Er is weinig anders te doen dan stilzitten en accepteren dat men geschoren wordt. Daar vloeit mogelijk enige rust uit voort, want geschoren worden is onvermijdelijk. Het onvermijdelijke voor de accountancysector is op dit moment dat er AQI's moeten worden gerapporteerd. In deze vorm van gelatenheid vervallen we van de mythe van de almacht in de mythe van het slachtofferschap (Dohmen 2007).

In het omgaan met tragiek is het in de eerste plaats belangrijk te erkennen dat tragiek bestaat. Vervolgens is het de kunst om het midden te zoeken tussen hoogmoed en fatalisme. Wij zien hier vijf aanknopingspunten voor:

- Mededogen

- Bescheiden trots

- Kwetsbaar opstellen

- Aan de slag met verhalen

- Permanent beraad accountancy 


\subsection{Mededogen}

De tragische held streeft 'het goede' na, maar realiseert door actief te handelen precies het tegendeel van wat hij beoogde. Is hij schuldig? Verdient hij straf en blaam? Een held is niet slechts slachtoffer van de omstandigheden (fatalisme), maar is ook geen heer en meester van de omstandigheden, waardoor al wat hij doet en bereikt hem volledig aan te rekenen is (hoogmoed). In dergelijke situaties past enig mededogen bij het beoordelen van mensen; heb oog voor de rol van tragiek. Dat geldt niet alleen voor het beoordelen van anderen, maar zeker ook voor het beoordelen van jezelf. Maak jezelf en anderen niet meer verwijten dan terecht is.

Het is belangrijk om mededogen te hebben met de accountants die AQI's rapporteren omdat deze activiteit veel bronnen van tragiek bevat. Datzelfde geldt voor de controlewerkzaamheden die accountants dagelijks uitvoeren en de fouten die daarbij (kunnen) worden gemaakt. Accountants zijn geen slachtoffer van fraude bij hun cliënten, maar zijn ook geen heer en meester in het ontdekken van fraude. Het zoeken naar het deugdzame midden begint met het zien van de omstandigheden die ongemerkt een grote invloed kunnen hebben op de uitkomst van het controleproces ('het goede' versus 'het kwade').

\subsection{Bescheiden trots}

Mensen zijn normaliter trots wanneer ze iets goed doen en dit ook door anderen wordt erkend. Dat draagt bij aan hun zelfrespect en eigenwaarde. Trots is daarmee een belangrijke drijfveer om vooruit te komen in het leven. Net zoals de omstandigheden bij de tragische held een rol hebben gespeeld in de mislukking, wordt het slagen van de trotse held mede bepaald door de omstandigheden die niet zelf zijn gekozen. Voor de tragische held is mededogen nodig om fatalisme te voorkomen. Omgekeerd is bescheidenheid nodig voor de trotse held om hoogmoed te voorkomen.

\subsection{Kwetsbaar opstellen}

We kunnen niet eenduidig vaststellen wat de kwaliteit is van accountantscontrole. Het rapporteren van AQI's gaat hier niets aan veranderen, hoeveel indicatoren we ook gebruiken. Op die manier lijkt kwaliteit op waarheid. Zoals wetenschapsfilosoof Popper (1963) al aangaf: we kunnen geen criteria benoemen voor waarheid en we kunnen niet aangeven hoe we kunnen bepalen of een bepaalde uitspraak waar is. Maar onze kennis kan zich wel ontwikkelen door te leren. Hetzelfde geldt voor controlekwaliteit: ook al hebben we geen eenduidige criteria voor het vaststellen van kwaliteit, de kwaliteit van de uitgevoerde controles kan zich wel ontwikkelen. De vraag is wat we daarmee precies gaan zien en wat daarvoor nodig is. Het vraagt volgens ons een kwetsbare opstelling waarin accountants de tragiek zichtbaar maken en omarmen.

De maatschappelijke beeldvorming over accountants zit ergens tussen hoogmoed - wij weten alles beter, luister en vertrouw ons - en fatalisme - sorry, wij modderen ook maar wat aan en maken vaak fouten. Ook in deze beeldvorming is het schipperen tussen twee uitersten. Accountants maken de tragische dimensie van hun werk zichtbaar door de dilemma's die zij tegenkomen te benoemen en hun worstelingen te laten zien. In het publieke debat zou meer ruimte moeten zijn voor accountants die laten zien welke lessen zij hebben geleerd van de fouten die zijn gemaakt, zonder dat ze gelijk worden afgerekend door de maatschappij. Hiermee kunnen onze gedachten over controlekwaliteit verder ontwikkelen. Dit vereist weliswaar een aanpassing van wet- en regelgeving omtrent aansprakelijkheid en geheimhouding, maar kan mogelijk bijdragen aan het voorkomen dat accountants zich de ogen uitsteken en de professie vaarwel zeggen.

\subsection{Aan de slag met verhalen}

We kunnen niet alles meten of maken. Het is hoogmoedig om te denken dat dit wel kan en fatalistisch om te ontkennen dat het nodig is. Meet daarom het meetbare, maar beweer niet dat alle aspecten van kwaliteit meetbaar zijn of tot cijfers kunnen worden gereduceerd. Dat mag echter geen vrijbrief zijn om achterover te leunen, want het publiek heeft recht op verantwoording door accountants. Anders kunnen accountants hun rol als vertrouwenspersoon van het maatschappelijk verkeer niet waarmaken. Daarom vinden wij het noodzakelijk dat naast een kwantitatieve verantwoording ook kwalitatief - met woorden - inzicht wordt gegeven in de aspecten en omstandigheden ten aanzien van controlekwaliteit. De tekortkoming van cijfers en het belang van het achterliggende verhaal werd driekwart eeuw geleden al opgemerkt door de Nederlandse historicus Johan Huizinga: "In het getal bezwijkt het verhaal" (Heijne 2020, p. 48).

In het verhaal bij de AQI's is het belangrijk om zowel de kracht als de tekortkomingen uit te leggen. Vertel dus het hele verhaal en beperk dat niet tot enkele kwantitatieve AQI's die inzicht geven in een beperkt onderdeel van controlekwaliteit. Dat staat werkelijke verandering en innovatie in de weg. Accountants moeten het verhaal zelf vertellen en daarmee inzicht geven in de controlekwaliteit die zij realiseren.

\subsection{Permanent beraad accountancy}

Tot slot: we leven in een wereld vol systemen, instituties en machtsconstellaties met een eigen dwingende logica, die goed handelen zoals bedoeld in Griekse tragedies moeilijker maken of zelfs onmogelijk (De Mul 2006). Dit geldt ook voor de discussies over de toekomst van de accountancysector waar veel verschillende partijen bij betrokken zijn. Iedereen probeert 'het goede' te doen en loopt het risico om als tragische held te eindigen. Alleen, er zijn geen schuldigen aan te wijzen - of we zijn het allemaal - en dan nog, om de Schotse socioloog Ferguson te parafraseren: systemen, instituties en machtsconstellaties zijn misschien het resultaat van menselijk handelen, maar niet per se van een menselijk ontwerp (vgl. De Mul 2006, p. 48). Dit betekent niet dat een menselijk ontwerp is uitgesloten of niet in enige vorm zou moeten worden nagestreefd. In het schipperen tussen hoogmoed en fatalisme zien wij daarom een 
belangrijke rol weggelegd voor een permanent beraad over controlekwaliteit. Een dergelijk beraad is een dialoog tussen accountants, toezichthouders, gebruikers, cliënten, beleidsmedewerkers, wetenschappers en media. Een beraad over de wederzijdse verwachtingen. Over het realiteitsgehalte van het beroep. Over het reductionisme in het opstellen en controleren van jaarrekeningen. Over de dilemma's en de worstelingen die accountants, maar wellicht ook andere partijen, meemaken. Om elkaar beter te begrijpen. Om de verwachtingen af te stemmen. En om samen te kijken hoe controlekwaliteit steeds verder kan ontwikkelen.

\section{Conclusies}

In dit artikel zijn wij dieper ingegaan op de suggestie van de CTA om AQI's te rapporteren. Hoewel deze suggestie een goede stap lijkt te zijn in het herwinnen van het vertrouwen in de accountancysector, hebben wij aan de hand van de tragiek uit de Griekse oudheid laten zien dat er omstandigheden zijn waarbij deze goede bedoeling kwade gevolgen kan hebben. Accountantscontrole omvat een reeks van activiteiten waarbij cijfers worden gecontroleerd die een weergave zijn van het reilen en zeilen van organisaties. Naast dat deze cijfers de werkelijkheid nooit volledig kunnen vatten, zijn de normen voor het opstellen en controleren van deze cijfers gebaseerd op principes die verschillend kunnen worden geïnterpreteerd. Daarbij komt dat de motivatie en professionele oordeelsvorming van accountants alsook de omstandigheden van controleopdrachten niet uniform en universeel zijn. Controlekwaliteit is daarom een sociaal geconstrueerd fenomeen. Daarenboven spelen inschattingen, en daarmee subjectiviteit, doorgaans een grotere en veel belangrijkere rol in de accountancysector dan wat in de maatschappij wordt gedacht. Op grond van deze argumenten komen wij tot de conclusie dat het rapporteren van AQI's afbreuk doet aan het unieke en specifieke karakter van de accountantscontrole, zodat de kloof tussen de visie van accountants en de maatschappij eerder wordt vergroot dan verkleind.

Wij hebben twee uitersten beschreven voor het reageren op de suggestie om AQI's te rapporteren: hoog- moed versus fatalisme. Een hoogmoedige houding gaat uit van de maakbaarheid van controlekwaliteit: het kan worden gemeten en vervolgens actief worden verbeterd. Een fatalistische houding gaat uit van passiviteit en slachtofferschap waarbij AQI's braaf worden omarmd en gerapporteerd in de hoop dat de tragiek daarmee verdwijnt. Beide reacties doen volgens ons geen recht aan de complexiteit van accountantscontrole. Daarom doen wij een oproep voor mededogen, bescheiden trots en een kwetsbare houding om vanuit deze positie verhalen te vertellen over de dagelijkse gang van zaken die positief bijdragen aan een leer- en ontwikkelproces in het accountantsberoep. Bij het zoeken naar het deugdzame midden tussen hoogmoed en fatalisme kunnen accountants gebruik maken van een permanent beraad waarin zij actief de dialoog aangaan met andere stakeholders om te voorkomen dat de accountancysector als een blinde ten onder gaat.

De tragiek in accountancy speelt niet alleen in het rapporteren van AQI's. De filosoof Dohmen (2007, p. 281) laat zien dat tragiek een dimensie is van ons bestaan:

"We zijn en blijven in allerlei opzichten kwetsbaar: fysiek (pijn, verdriet, ziekte en de dood), cognitief (onwetendheid, vergissing, onzekerheid), emotioneel (verliefdheid, woede, haat en afgunst) en motivationeel (onmacht, traagheid, verwarring). Bovendien is het leven vaak onrechtvaardig en onvoorspelbaar. We worden miskend en gekwetst. We zijn niet op het juiste moment op de juiste plaats. We worden het slachtoffer van een tragisch misverstand. En dan krijgen we ineens wat we niet verdienen en waar we ook geen recht op hebben. Ook mazzel is onrechtvaardig. Het meest wezenlijke punt is misschien wel dit: zelfs als we handelen naar onze allerbeste inzichten en in alle oprechtheid menen het goede te doen, dan nog is er geen enkele garantie dat we krijgen wat we verdienen."

Accountants ontsnappen in hun werk niet aan deze dimensies van tragiek. Verder onderzoek is nodig om een beter begrip te krijgen van de rol van tragiek in de accountancy. Om op die manier nog beter te begrijpen wat accountants doen, wat van hen mag worden verwacht en waar ze redelijkerwijs op mogen worden aangesproken.

Dr. Herman van Brenk RA is universitair docent accountancy aan Nyenrode Business Universiteit.

Dr. Edgar Karssing is universitair hoofddocent beroepsethiek en integriteitsmanagement aan Nyenrode Business Universiteit.

- Prof. dr. Ivo De Loo is hoogleraar management accounting en control aan Nyenrode Business Universiteit.

- Prof. dr. Barbara Majoor RA is hoogleraar accountancy aan Nyenrode Business Universiteit en werkzaam bij de Autoriteit Financiële Markten.

\section{Noot}

1. Passages over de kerngedachten rondom tragiek zijn ontleend aan Karssing (2018). 


\section{Literatuuir}

- Aristoteles (1997) Ethica Nicomachea. Kallias (Amsterdam).

- Briloff A (1972) Unaccountable accounting. Harper \& Row (New York).

- Causholli M, Knechel W (2012) An examination of the credence attributes of an audit. Accounting Horizons 26(4): 631-656. https:// doi.org/10.2308/acch-50265

- Christensen B, Glover S, Omer T, Shelley M (2016) Understanding audit quality: Insights from audit professionals and investors. Contemporary Accounting Research 33(4): 1648-1684. https://doi. org/10.1111/1911-3846.12212

- CTA [Commissie Toekomst Accountancysector] (2020) Vertrouwen op controle. Rapportvan de Commissie toekomstaccountancysector.https:// www.rijksoverheid.nl/binaries/rijksoverheid/documenten/kamerstukken/2020/01/30/vertrouwen-op-controle-eindrapport-van-de-commissie-toekomst-accountancysector/vertrouwen-op-controle-eindrapport-van-de-commissie-toekomst-accountancysector.pdf

- De Mul J (2006) De domesticatie van het noodlot. Klement/Pelckmans.

- Demirag I, Khadaroo I (2011) Accountability and value for money: A theoretical framework for the relationship in public-private partnerships. Journal of Management \& Governance 15(2): 271-296. https://doi.org/10.1007/s10997-009-9109-6

- Detzen D, Gold A(2021)A review of the academic literature of the different shades of audit quality. Maandblad voor Accountancy en Bedrijfseconomie 95(1/2): 5-15. htps://doi.org/10.5117/mab.95.60608

- De Vries M, Fonteijn C, Mellink D, Boontjes J (2020) Plan van aanpak kwartiermakers toekomst accountancysector. https://www.linkedin.com/company/kwartiermakers-toekomst-accountancysector/

- Dohmen J (2007) Tegen de onverschilligheid. Pleidooi voor een moderne levenskunst. Ambo (Amsterdam).

- Ezzamel M, Burns J (2005) Professional competition, economic value added and management control strategies. Organization Studies 26(5): 755-777. https://doi.org/10.1177/0170840605054598

- FRC [Financial Reporting Council] (2020) Audit quality indicators: AQR thematic review. London: FRC. https:/www.frc.org.uk/getattachment/f116f7d7-94d8-4c82-94b2-ba24e3b195eb/AQTR_AQI_Final.pdf

- Gambling T (1977) Magic, accounting and morale. Accounting, Organizations and Society 2(2): 141-151. https://doi.org/10.1016/03613682(77)90031-9

- Gambling T (1987) Accounting for rituals. Accounting, Organizations and Society 12(4): 319-329. https://doi.org/10.1016/03613682(87)90021-3

- Heijne B (2020) Onbehagen. Prometheus (Amsterdam).

- Humphrey C, Canning M, O’Dwyer B (2018) Audit quality and inspection in the Netherlands: The importance of an intellectual approach to experiential learning and practice advancement. Maandblad voor Accountancy en Bedrijfseconomie 92(1/2): 7-19. https://doi. org/10.5117/mab.92.24418
- Karssing E (2018) Als de oplossing het probleem is. Compliance met een moreel kompas. NCI (Capelle aan den IJssel).

- Knechel W, Krishnan G, Pevzner M, Shefchik L, Velury U (2013) Audit quality: Insights from the academic literature. Auditing: A Journal of Practice \& Theory, 32(Supplement 1): 385-421. https:// doi.org/10.2308/ajpt-50350

- Macintosh N (2009) Accounting and the truth of earnings reports: Philosophical considerations. European Accounting Review 18(1): 141-175. https://doi.org/10.1080/09638180802327073

- Majoor B (2016) Audit quality indicators; het ei van Columbus? Maandblad voor Accountancy en Bedrijfseconomie 90(4): 112-115. https://doi.org/10.5117/mab.90.31281

- Majoor B (2020) Bruggen bouwen tussen verwachtingen en percepties? Maandblad voor Accountancy en Bedrijfseconomie 94(1/2): 1-3. https://doi.org/10.5117/mab.94.50958

- MCA [Monitoring Commissie Accountancy] (2020) Spiegel voor de accountancysector. Veel problemen zijn helemaal niet nieuw, ze keren alleen telkens terug. http://www.monitoringaccountancy. nl/wp-content/uploads/2020/01/Eindrapport-Monitoring-Commissie-Accountancy-140120.pdf

- Morgan G (1988) Accounting as reality construction: Towards a new epistemology for accounting practice. Accounting, Organizations and Society 13(5): 477-485. https://doi.org/10.1016/03613682(88)90018-9

- NBA [Nederlandse Beroepsorganisatie van Accountants] (2020) Handleiding Regelgeving Accountancy. https://www.nba.nl/tools/ hra-2020/?document $=118813$

- Popper K (1963) Conjectures and refutations: The growth of scientific knowledge. Routledge (London). https://doi.org/10.1063/1.3050617

- Porter B (1993) An empirical study of the audit expectation-performance gap. Accounting and Business Research 24(93): 49-68. https://doi.org/10.1080/00014788.1993.9729463

- Quick R (2020) The audit expectation gap: A review of the academic literature. Maandblad voor Accountancy en Bedrijfseconomie 94(1/2): 5-25. https://doi.org/10.5117/mab.94.47895

- Sterling R (1979) Towards a science of accounting. Scholars Book Company (New York).

- Stewart D, Mickunas A (1974) Exploring phenomenology: Guide to field and its literature. American Library Association (Chicago).

- Van Brenk H, Van Buuren J, Renes R, De Vries M (2017) Consultatie green paper "De definitie van audit kwaliteit". https:/www.nba. nl/globalassets/projecten/in-het-publiek-belang/green-paper-andwhite-paper-audit-kwaliteit/consultatie-green-paper-audit-kwaliteit-nyenrode-business-universiteit-september-2017.pdf

- Van Buuren J (2015) Controlekwaliteit blijft een belevenis. Maandblad voor Accountancy en Bedrijfseconomie 89(3): 67-76. https:// doi.org/10.5117/mab.89.31257 